\title{
IMPACT OF CHEMICAL HERBICIDES TO BREAD WHEAT GENOTYPES (Triticum aestivum $\mathbf{L}$ ) \\ M.R.A. Al-Latif
}

Assist. Prof.

Dept.Field Crops Coll. Agriculture. Tikrit University, Iraq

Mmaar79@tu.edu.iq

\section{ABSTRACT}

This study was aimed to investigate effect of wheat cultivates to herbicides. A field experiment was conducted at the Research Station of the Field Crops Department at the College of Agricultural , University of Tikrit during winter season 2017-2018. Factorial Experiment within Randomized Complete Block design with three replicates were used . This experiment contains two variables first was used the herbicide (Atlantis, Pallas, Chevalier) and control. The second variable includes four cultivates (Al-Hashimiyah, AlBaraka, Nor, and Door 29). The results Al-Baraka revealed that the highest plant height $(75.91 \mathrm{~cm})$, number of spikes $\left(372.67 \mathrm{~m}^{2}\right)$ and the number of shoots $\mathrm{m}^{2}(355.41)$, while the cultivate Noor had the highest value, number of grains $\operatorname{spike}^{-1}(42.67)$ and the total grain yield (4.82) ton ha $^{-1}$. Atlantis herbicide recorded the highest number of tillers square meter ${ }^{-1}$ (387.50) and the treatment Balas recorded the highest value in the weight of a thousand grains $(40.24 \mathrm{~g})$ and total grain yield $\left(2.00\right.$ tons. $\left.\mathrm{ha}^{-1}\right)$. The interaction between genotypes and pesticides produced highest grain yield (6.31) tons.ha ${ }^{-1}$.

Key words: soft wheat genotypes, weeds, grain yield , yield components

Triticum aestivum L. تأثير مبيدات الادغال الكيمياوية على تراكيب وراثية من الحنطة

$$
\begin{aligned}
& \text { محمد رمضان أحمد ألطيف من } \\
& \text { استاذ مساعد } \\
& \text { كلية ألزراعة/ جامعة تكريت ـ ألعرلق }
\end{aligned}
$$

المستخلص

أجريت تجرية حقلية في محطة أبحاث قسم ألمحاصيل ألحقلية ألتابع ألى حقول كلية ألزراعة في جامعة تكريت في ألموسم ألثتوي 2017-2018 بهدف معرفة تفاعل تراكيب وراثية من الحنطة Triticum aestivum L. لمبيدات الأدغال

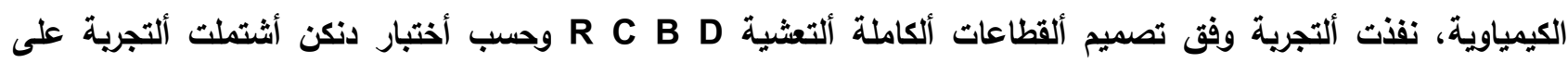

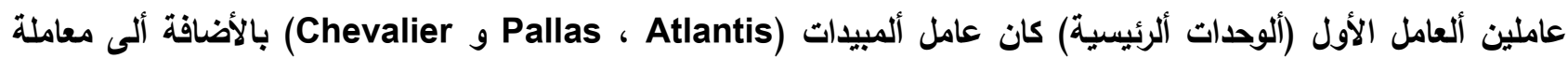

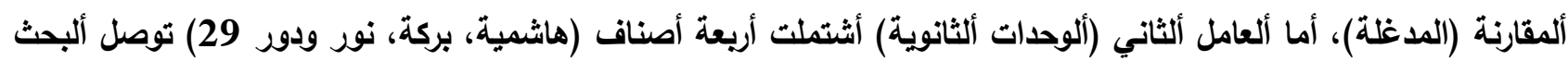

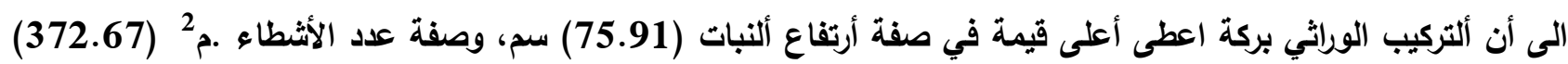
وصفة عدد ألسنابل.م² (355.41)، في حين سجل ألتركيب الوراثي نور أعلى قيمة في صفة عدد ألحبوب. ألسنبلة (42.67)

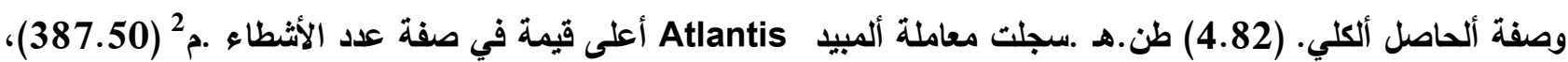

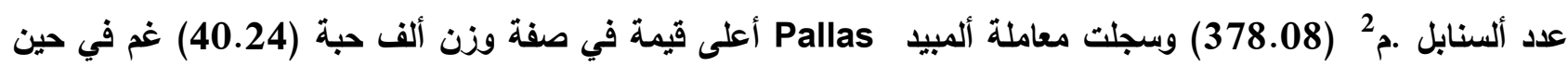
سجلت معاملة المقارنة (المدغلة) أقل قيمة في صفة ألحاصل ألكلي (2.00) طن.هـ .ألتذاخل ألثنائي بين ألتراكيب الوراثية والمبيدات سجل أعلى قيمة في في معاملة ألمبيد مallas وللتركيب لحاصل الكلي ويلغت (6.31) طن. هـ. الكلمات المفتاحية: تراكيب الحنطة الوراثية، أدغال، مبيدات أدغال. 


\section{INTRODUCTION}

The bread wheat grain yield ranks first in the world's cereal crops in terms of cultivated area and economical, as it provides people with more than $25 \%$ of protein and calories. It is an important food source for more than 1.5 billion peoples, representing $35 \%$ of the world's population (10). The productivity of this crop increased per unit area at the beginning of the current century as a result of the use of improved genotypes, various pesticides, the development of fertilizers and the utilization of agricultural mechanization on a large scale. Cereal are considered one of the most important crop, including the bread wheat, which is considered the weakest competitor to weeds compared to other crops (14). As well as the reduction caused by these crops to the agricultural sector with its animal and increases in the costs management, and losses caused by weed exceed the losses caused management (1). Herbaceous plants compete with crop plants on the main growth components (water, light and nutrients) especially in the early stages of growth, as a result of the fierce competition. The growth of the crop is weak, and this is directly reflected in the outcome in terms of quantity and quality. The use of chemical herbicides is one of the easiest methods of weed control, and it has a great positive economic benefit. It also provides high effectiveness and variation of the genotypes of the soft wheat crop in its tolerance to herbicides and the response to chemical herbicides. This study was aimed to investigate the effect of herbicides to several wheat cultivars.

\section{MATERIALS AND METHODS}

A field experiment was carried out at the Field Crops Department, College of Agriculture, Tikrit University during 2017-2018 season. The experiment aims to determine response of wheat genotypes, (Hashemite, Baraka, Noor and Dor 29) to herbicides (Atlantis $3.6 \mathrm{wt} . \%$ ), Chevalier and Pallas 4.5 wt.\%) at the recommended concentrations for each pesticide $(80 \mathrm{~g} /$ dunum, $300 \mathrm{~g} / \mathrm{ha}$ and 125 $\mathrm{ml} /$ dunum respectively), and control treatment (sprayed with distilled water). The field plowed by two perpendicular plows with the dump plow and smoothed by the disc harrows and the leveling was done with the screed. The
Factorial Experiments within Randomized Complete Block Design (RCBD) with three replicates was used. The herbicide occupied the main plots, while the genotypes within sub plots. The experimental field was divided into experimental units of $8 \mathrm{~m}^{2}(4 \mathrm{~m} \times 2 \mathrm{~m})$. The seeds were sown manually on the lines distance between lines was $20 \mathrm{~cm}$. In $11 / 21 / 2017$ and 30/5/2018, the experimental field was irrigated, and the irrigation was repeated whenever needed. A fertilizer was used at a rate of $240 \mathrm{~kg} / \mathrm{ha}$ (Urea $46 \%$ ). The first batch was $100 \mathrm{~kg} / \mathrm{ha}$ with the whole batch of triple superphosphate fertilizer $\left(\mathrm{P}_{2} \mathrm{O}_{5} 46 \%\right)$, while the remaining quantity of the urea fertilizer was added after 45 days from seeding (13). A dorsal sprinkler was used at a rate of 400 liters/h. The pesticides were used in the stage of 2-4 leaves age of broad weeds and 3-6 leaves of the thin-leafed weeds.

\section{RESULTS AND DISCUSSION}

Types and density of weed plants at the field during the study season: Types of the broad-leaved weeds developed at study field were identified as Sonchus oleraceus, Silybum marianum, Beta valgaris, Convolvulus arvensis, Daucus carota, Malva rolundifolia, thin-leafed herbs Avena Fatua L., Phalaris minor and Lolium rigidum. The proportion of wide-leaved herbs was around $60 \%$ and $40 \%$ for the narrow herbs. Result in Table 1 show that the herbicide effect a significant decreases to density of the associated weeds compared to the control treatment. This is in agreement with previous studies investigated the effect of the herbicides on controlling of weeds growth $(16,23)$. They confirmed that the use of chemical herbicides led to a significant reduction weeds density. The results of Table 1 showed that the Hashemite genotype was less competitive with the weeds. The reason for this is due to the differences in the genetic nature between the genotypes for competition with herbs or their differences in their growth and ability to inhibit the weeds growth. Their ability on the competition for the main growth requirements was obviously different. These results agree with (12). It could be observe from the same Table that there is a significant bilateral overlap between the pesticides and the genotypes where the results recorded the use of Nor and Dor 29 with treatment of the 
Chevalier herbicides had excellent weeds control. Also, the treatment by Hashemite, with the control treatment, achieved the highest average $\left(47.67 \mathrm{grass} / \mathrm{m}^{2}\right)$, this result agreed with the results of another researcher $(8,1520)$.

Table 1. Effect of the genotypes of soft wheat and chemical herbicides on characteristics of weeds density

\begin{tabular}{|cccccc|}
\hline Genotypes & Chevalier & Pallas & Atlantis & Control & Means \\
\hline Hashemia & 2.67 & 5.33 & 1.67 & 47.67 & 14.33 \\
& def & d & Ef & a & a \\
Baraka & 3.00 & 00.00 & 4.67 & 20.00 & 6.92 \\
& def & f & De & c & bc \\
Nor & 00.00 & 0.67 & 1.33 & 21.33 & 5.83 \\
& f & f & Ef & c & c \\
Dour 29 & $\mathbf{0 0 . 0 0}$ & $\mathbf{0 . 3 3}$ & $\mathbf{0 . 3 3}$ & $\mathbf{3 2 . 6 7}$ & $\mathbf{8 . 3 3}$ \\
& f & f & f & b & b \\
Means & $\mathbf{1 . 4 2}$ & 1.6 & 2.22 & 30.42 & \\
& b & b & B & a & \\
\hline
\end{tabular}

* Values followed by the same letters in the same row or same column were not significantly different at $P=0.05$.

\section{Plant height}

Data in Table 2, shows that the highest plant height recorded at the control treatment (78.6 $\mathrm{cm}$ ), which was significantly higher than the pesticide treatments. The latter did show significant differences among their plant's height as the increases with the increasing of plant density. This increase caused to increase shading, which stimulates the activity of auxins with gibberellins to increase the elongation of the phalanges and resulted in an increases in plant height (21). This describes the high density of weeds in the control treatments compared to the pesticide treatments. It is reveal from the same Table that the composition Baraka and Dor 29 was superior, this may attributed to the variation of the genotypes in the phenotypic characteristics of the bilateral overlap, and the significant superiority of the genotype that was obtained in the treatment of the control at a rate of 82 $\mathrm{cm}$. This is an indication of the tolerance of the composition Baraka for weeds treatment and the increases in the action of auxins and gibberellins in this high density. Genetic characteristics related to the inherited composition characteristics and perhaps its ability to compete with herbs for the main growth requirements, especially food, water and light, its speed of germination emergence, and its rapid growth. These factors helped in escape the period of early and critical competition for the herbivore and has also been attributed to morpholithic factors related to the elongation of its roots, the composition of the vegetative system, and its ability to shade $(25,26)$.

Table 2. Effect of the genotypes of soft wheat and chemical herbicide on plant height.

\begin{tabular}{|cccccc|}
\hline Genotypes & Chevalier & Pallas & Atlantis & Control & Means \\
\hline Hashemia & $\mathbf{7 2 . 3 3}$ & $\mathbf{7 0 . 3 3}$ & $\mathbf{7 0 . 0 0}$ & $\mathbf{7 6 . 3 3}$ & $\mathbf{7 2 . 2 5}$ \\
& bc & cd & cd & b & b \\
Baraka & 73.67 & $\mathbf{7 4 . 0 0}$ & $\mathbf{7 4 . 0 0}$ & $\mathbf{8 2 . 0 0}$ & $\mathbf{7 5 . 9 1}$ \\
& bc & bc & bc & a & a \\
Nor & $\mathbf{7 4 . 0 0}$ & $\mathbf{6 6 . 6 7}$ & $\mathbf{6 6 . 6 7}$ & $\mathbf{7 3 . 6 7}$ & $\mathbf{7 0 . 2 5}$ \\
& bc & d & d & bc & b \\
Dour 29 & $\mathbf{7 2 . 3 3}$ & $\mathbf{7 2 . 6 7}$ & $\mathbf{7 3 . 3 3}$ & $\mathbf{8 2 . 3 3}$ & $\mathbf{7 5 . 1 6}$ \\
& bc & bc & bc & a & a \\
Means & $\mathbf{7 3 . 1}$ & $\mathbf{7 0 . 9 1}$ & $\mathbf{7 1 . 0 0}$ & $\mathbf{7 8 . 6}$ & \\
& b & b & b & a & \\
\hline
\end{tabular}

* Values followed by the same letters in the same row or same column were not significantly different at $\mathbf{P}=0.05$

\section{Spike length}

The results in Table 3 show that the average pesticide treatments were statistically superior when compared to the control treatment. This could be attribute to the best growth conditions, which improved the ability of these plants (control treatments) to compete with the weeds and caused an increase the spike length. This result is consistent with several ongoing research of cereal crops, including wheat and barley, both cultivated tropically or dime, when combating weeds at 2-4 wide leaf and 36 thin leaf. This could be reduced the competition for moisture, nutrients and light, 
which caused increases the growth rate in favor of crop plants and gave highest yield compared to the treatments (9). As for the genotypes, it is clear that the combination of Baraka had the lowest value, while the combination of Nor had the highest value. This results consistent with the results of several research that found that combination or hybrids of crops in general and wheat types in special varies in softness, sensitivity, tolerance, or response to a specific herbicide or group of herbicides, $(7,11,20,27)$.

Table 3. Effect of the genotypes of soft wheat and chemical herbicides on characteristics of spike length

\begin{tabular}{|c|c|c|c|c|c|}
\hline Genotypes & Chevalier & Pallas & Atlantis & Control & Means \\
\hline Hashemia & $\begin{array}{c}13.67 \\
\text { a }\end{array}$ & $\begin{array}{c}14.00 \\
a\end{array}$ & $\begin{array}{c}13.00 \\
\text { a }\end{array}$ & $\begin{array}{c}9.00 \\
b\end{array}$ & $\begin{array}{c}12.41 \\
\text { ab }\end{array}$ \\
\hline Baraka & $\begin{array}{c}13.67 \\
\text { a }\end{array}$ & $\begin{array}{c}13.00 \\
\text { a }\end{array}$ & $\begin{array}{c}13.67 \\
\text { a }\end{array}$ & $\begin{array}{c}9.00 \\
b\end{array}$ & $\begin{array}{c}12.33 \\
b\end{array}$ \\
\hline Nor & $\begin{array}{c}14.67 \\
a\end{array}$ & $\begin{array}{c}14.33 \\
\mathrm{a}\end{array}$ & $\begin{array}{c}14.00 \\
\mathrm{a}\end{array}$ & $\begin{array}{c}10.00 \\
b\end{array}$ & $\begin{array}{c}13.3 \\
\text { a }\end{array}$ \\
\hline Dour 29 & $\begin{array}{c}14.33 \\
\text { a }\end{array}$ & $\begin{array}{c}13.33 \\
\mathbf{a}\end{array}$ & $\begin{array}{c}13.33 \\
\mathbf{a}\end{array}$ & $\begin{array}{c}10.33 \\
b\end{array}$ & $\begin{array}{c}12.83 \\
\text { ab }\end{array}$ \\
\hline Means & $\begin{array}{c}14.08 \\
a\end{array}$ & $\begin{array}{c}13.67 \\
\text { a }\end{array}$ & $\begin{array}{c}13.50 \\
a\end{array}$ & $\begin{array}{c}9.58 \\
b\end{array}$ & \\
\hline
\end{tabular}

* Values followed by the same letters in the same row or same column were not significantly different at $\mathbf{P}=0.05$

\section{Tillers number $\mathbf{m}^{-2}$}

The results in Table 4 indicate the superiority of the treatment by the pesticide Atlantis, with a statistical superiority of 387.50 tillers $\mathrm{m}^{-2}$, followed by the pesticide Pallas, which was followed statistically, where it was 372.33 tillers $\mathrm{m}^{-2}$, followed by a significant treatment of the pesticide Chevalier at a rate of 339.3 tillers $\mathrm{m}^{-2}$. Whereas the treatment of the control recorded the lowest value (244.33 tillers $\mathrm{m}^{-2}$ ). The reason for this could be attributed to the reduction or lack of competition for the main growth components, which help to an increase in the number of tillers. This results was in agreement with (5), where they found that the pesticide Atlantis achieved the highest rate in the number of tillers. The results of the same Table showed that the combination of Baraka achieved the highest rate, followed by the Hashemite, and then the Dor 29 and the composition of Nur achieved the lowest value. These results agreed with others (17) who explained the difference in compositions in the competitiveness ability and this was reflected in the outcome and its components. It was agreed with the resulting of other researcher (5) as the bilateral overlap between the combinations and pesticides was significant as the composition achieved an outstanding treatment by the pesticide Pallas at a rate of $466.67 \mathrm{psi} / \mathrm{m}^{2}$, this shows the competition between the main growth factors and the positive effect of pesticides in reducing this competition. The increases in the number of tillers due to weed control gave a positive indication in improving productivity, when associated with the results obtained in these shoots of fertile spike (18). However, the limiting factor for the growth of these tillers is the amount of interaction between the plants or the tillers themselves on the elements necessary for growth of water, minerals and light (16).

Table 4. Effect of the genotypes of soft wheat and chemical herbicides on the characteristic of the number of tillers $\mathrm{m}^{-2}$

\begin{tabular}{|cccccc|}
\hline Genotypes & Chevalier & Pallas & Atlantis & Control & Means \\
\hline Hashemia & $\mathbf{3 8 1 . 3 3}$ & $\mathbf{3 7 8 . 6 7}$ & $\mathbf{3 5 4 . 6 7}$ & $\mathbf{2 6 8 . 0 0}$ & $\mathbf{3 4 5 . 6 7}$ \\
& c & c & cd & fg & b \\
Baraka & 382.67 & 466.67 & 428.00 & 213.33 & 372.67 \\
& c & a & b & i & a \\
Nor & 293.00 & 306.67 & 384.00 & 238.67 & 305.58 \\
& ef & e & c & hi & d \\
Dour 29 & 300.00 & 337.33 & 383.33 & 257.33 & 319.50 \\
& e & d & c & gh & c \\
Means & 339.3 & 372.33 & 387.50 & 244.33 & \\
& c & b & a & d & \\
\hline
\end{tabular}

* Values followed by the same letters in the same row or same column were not significantly different at $\mathbf{P}=0.05$ 
Number of spikes $\mathbf{m}^{-2}$

The results of Table 5 show the effect of studied treatments on the number of spikes $\mathrm{m}^{-}$

${ }^{2}$, where it is reveal that the control treatment recorded the lowest significant value at a rate of tillers $224.3 \mathrm{~m}^{2}$, while the highest statistical value of the pesticide Atlantis was 378.08 tillers $\mathrm{m}^{2}$, followed by Chevalier at 358 tillers $\mathrm{m}^{2}$. This results were agreed with the results of others (21), also the Table 5 indicate that the combination of Barakah was significantly superior at a rate of $355.41 \mathrm{~m}^{2}$, followed by the combination of Hashemite, at a rate of $331.83 \mathrm{~m}^{2}$. The combinations Dor 29 and Nor did not differ significantly as their rates were 299.58 and $294.50 \mathrm{~m}^{2}$. It was observed that there is a variation in genotypes tolerance to the pesticides and their sensitivity to the associated weeds. The interaction between the pesticides and genotypes was significant, as a significant superiority recorded in the genotype of Baraka for the treatment of the pesticide Pallas with a rate of $448 \mathrm{~m}^{2}$.

Table 5. Effect of the genotypes of bread wheat and chemical herbicides on the characteristic of the number of spikes $\mathrm{m}^{-2}$

\begin{tabular}{|cccccc|}
\hline Genotypes & Chevalier & Pallas & Atlantis & Control & Means \\
\hline Hashemia & $\mathbf{3 8 1 . 3 3}$ & $\mathbf{3 7 8 . 6 7}$ & $\mathbf{3 5 4 . 6 7}$ & $\mathbf{2 6 8 . 0 0}$ & $\mathbf{3 4 5 . 6 7}$ \\
& c & c & cd & fg & b \\
Baraka & 382.67 & 466.67 & 428.00 & 213.33 & 372.67 \\
& c & a & b & i & a \\
Nor & 293.00 & 306.67 & 384.00 & 238.67 & 305.58 \\
& ef & e & c & hi & d \\
Dour 29 & 300.00 & 337.33 & 383.33 & 257.33 & 319.50 \\
& e & d & c & gh & c \\
Means & 339.3 & 372.33 & 387.50 & 244.33 & \\
& c & b & a & d & \\
\hline
\end{tabular}

* Values followed by the same letters in the same row or same column were not significantly different at $P=0.05$

Number of grains spike ${ }^{-1}$

The results in Table 6 show that the control treatment recorded the lowest rate of 22.67 grains spike ${ }^{-1}$, while the treatment of Chevalier recorded the highest statistically value at a rate of 40.67 grains spike ${ }^{-1}$, which did not differed significantly from the treatment of the pesticide Pallas, where had average number of grains spike ${ }^{-1}$ was 38.75 . This could be attributed to the provision of a suitable environment for wheat plants to develop without competing with the requirements of growth. This was reflected to the growth activities and produced greater amount of the growing grains due to increase their knots and reduce their abortion. For the genotypes, a significant differences were recorded between the averages of the number of grains spike ${ }^{-1}$, and this reveals the genetic differences, as shown for the Nor combination. Also, the bilateral interference was significant, where the genotype of the Pallasite was significantly superior to the genotype of the treatment of the pesticide Pallas at a rate of 54.67 grains spike $^{-1}$

Table 6. Effect of the genotypes of soft wheat and chemical herbicides on the characteristic of the number of grains spike ${ }^{-1}$

\begin{tabular}{|cccccc|}
\hline Genotypes & Chevalier & Pallas & Atlantis & Control & Means \\
\hline Hashemia & 26.67 & 32.67 & $\mathbf{3 4 . 0 0}$ & $\mathbf{1 8 . 3 3}$ & 27.91 \\
& fg & ef & E & h & c \\
Baraka & 37.00 & 26.33 & 33.00 & 23.00 & 29.83 \\
& de & fg & Ef & gh & c \\
Nor & 47.33 & 54.67 & 44.00 & 24.67 & 42.67 \\
& bc & a & C & gh & a \\
Dour 29 & $\mathbf{5 1 . 6 7}$ & $\mathbf{4 1 . 3 3}$ & $\mathbf{3 2 . 6 7}$ & $\mathbf{2 4 . 6 7}$ & 37.58 \\
& ab & cd & Ef & gh & b \\
Means & 40.67 & 38.75 & 35.91 & 22.67 & \\
& a & ab & B & c & \\
\hline
\end{tabular}

* Values followed by the same letters in the same row or same column were not significantly different at $P=0.05$ Grams weight ( 1000 grains $\mathrm{g}^{-1}$ )

It is reveal from the results in Table 7 that a significant superiority of the herbicide treatment Pallas, where the highest rate was recorded at $40.24 \mathrm{~g}$, while the control treatment recorded the lowest value with an average of $37.20 \mathrm{~g}$. "This result reflects the intensity of competition for the basic growth 
factors (water, light and nutrients) between weeds and crop plants. On the other hand, the positive role of the herbicides used in the experiment was shown by reducing competition between wheat crop plants and the associated weeds. The same Table shows the superiority of the Hashemite genotype. These results agreed with other result (7). The bilateral interaction between genotypes and pesticide treatments was significant, as the Hashemite composition of the Pallasite treatment achieved the highest average 42.53 g.

Table 7. Effect of the genotypes of soft wheat and chemical herbicides on the weight characteristic of a thousand grains

\begin{tabular}{|cccccc|}
\hline Genotypes & Chevalier & Pallas & Atlantis & Control & Means \\
\hline Hashemia & $\mathbf{4 0 . 2 3}$ & 42.53 & 40.90 & 38.73 & 40.60 \\
& Abc & a & ab & a-e & a \\
Baraka & 37.07 & 40.07 & 40.33 & 35.10 & 38.14 \\
& b-e & abc & abc & e & b \\
Nor & 39.60 & 37.47 & 39.17 & 36.17 & 38.10 \\
& a-d & b-e & a-d & de & b \\
Dour 29 & 36.93 & 40.90 & 38.77 & 38.83 & 38.85 \\
& Cde & ab & a-e & a-e & b \\
Means & 38.45 & 40.24 & 39.79 & 37.20 & \\
& Bc & a & ab & c & \\
\hline
\end{tabular}

* Values followed by the same letters in the same row or same column were not significantly different at $P=0.05$ Grain yield (t.ha ${ }^{-1}$ ) of the combination Nor over the combinations The weed control with Pallas effect a significantly to the total grain yield, with an average of 5.25 tons $\mathrm{ha}^{-1}$, which indicates that the pesticide an excellent weed control. On the other hand, it shows that the weed plants associated with the crop had a negative effect on the grain yield of the crop. The control treatment showed the lowest statistical average (2.00 tons $\left.\mathrm{ha}^{-1}\right)$. These results agree with (25) Ishati results show that the superiority in grain yield was due to the excellent characteristics of 1000 grain weight and grains spike ${ }^{-1}$. When comparing general rates of genotypes for all treatments it was showed that there are significant differences between the grain yield of the grains development and the superiority used in the present study. The bilateral overlap between the combinations treatments and the pesticides was significant, and this means that there is a variation of the genotypes in their response to the herbicide treatments. The use of chemical herbicides for weed control led to reduce competition with the crop, which in turns led to the provision of good conditions for better growth of the crop. In comparing of the results of the grain yield of the different combinations of wheat and according to the herbicide treatments used and the overlap between them with the results of previous research it was noticed that there is a great agreement with several other results $(5,28)$.

Table 8. Effect of the genotypes of bread wheat and chemical herbicides on the grain yield characteristic ton ha ${ }^{-1}$

\begin{tabular}{|cccccc|}
\hline Genotypes & Chevalier & Pallas & Atlantis & Control & Means \\
\hline Hashemia & 3.83 & 4.78 & 4.41 & 1.74 & 3.69 \\
& g & def & f & h & d \\
Baraka & 4.91 & 4.64 & 4.71 & 1.92 & 4.04 \\
& def & ef & ef & h & c \\
Nor & 5.01 & 6.31 & 5.87 & 2.11 & 4.82 \\
& cde & a & ab & h & a \\
Dour 29 & 5.43 & 5.24 & 4.49 & 2.25 & 4.35 \\
& bc & cd & ef & h & b \\
Means & 4.79 & 5.25 & 4.87 & 2.00 & \\
& b & a & b & c & \\
\hline
\end{tabular}

$=*$ Values followed by the same letters in the same row or same column were not significantly different at $\mathrm{P}=0.05$

REFERENCES

1. Al Memar, Anwar and Ghassan Ibrahim.

2011. Harmful Herbs and Their Control. The
Theoretical Part . Damascus University Publications. pp. 384 
2. El-Sahooki, M.M, A.O. Al Falahi, and A.S. Al-Muhammadi. 2009. Crop, soil and breeding management for drought tolerance. Iraqi Journal of Agricultural Sciences. 40 (2): 1-28.

3. Al-chalabi , Faik T., and A. F. J. Aljebbori . 2012. Magnetized irrigation water and weed control with atrazine and their Impact on maiz growth analysis parameters . The Iraqi Journal. of Agriculture sciences. 43(5):24-32

4. Al-Obaidi, M.A. and H.A.W. Jadoua, 2002. Achieving self-sufficiency in the strategic grain by improving productivity per unit area. Arab Food Industries Journal. 1-2: 50-54.

5. Antar, S.H. and M.S.J Al-Badr. 2012. The effect of agricultural systems and chemical pesticides on the growth of Triticum aestivume and the associated bush. Kirkuk University Journal of Agricultural Sciences. 3 (2): 89-110.

6. Arab Organization for Agricultural Development. 2003. The National Workshop on Assessing the Environmental Impacts of Genetically Modified Plant and Animal Species in the Arab Region. Khartoum. The Republic of Iraq.pp: 190

7. Bailey ,W.A.,H.P. Wilson, D.E.Brain and C.A. Griffey .2004. Wheat Cultivar Tolerance $.18: 881-886$

8. Challaiah , J.M. and W.B. Meredith .1983. Yield of three cotton (Gossypium hirsutum ) cultivars as influenced by spurred Anoda (Anoda cristata ) competition . Weed Science . 31: 303-307

9. Chaudhary , S.U., M.Hussain , M.Anjum Ali and J.Iqbal . 2008. Effect of weed competition period on yield and yield components of wheat Journal Agriculture Research. 46 (1):47-53

10. Cimmy . 1996. World wheat facts and trend. understanding global trends in the use of wheat diversity and international flow of wheet . Genetics Resource . .pp:73

11. Clay, A.C,Thir and V.L. Conchran . 1988. Response of spring barley (Hordeum vulgare ) to herbicides. Weed Technology. 2:68-71

12. Habib,Showkat A., W. M. Jassim and M.A. Ai-falahi . 2002. Response and tolerance of five corn (zea mays L.) cultivars and companion weeds to several herbicides .IPA J. Agriculture Research 12(4):128-142
13. Jadoua, Khudair Abbas. 1995. Wheat, facts and tips. Publications of the Ministry of Agriculture. The General Authority for Agricultural Extension and Cooperation. Baghdad . Iraq.pp: 25 pages

14. Johnson , B. and E.Frick . 2002 . Growing a competitive crop - first step in weed control . Research Report . Scott Research farm 123124

15. Korres , N.E. and R.J.Froud - William 2002. Effect of winter wheat cultivars and seed rate on the biological characteristic of naturally occurring weed flora . Weed Research. 42(6):417-428 . DOI: https:// doi.org/10.1046/j.1365-3180.2002.00302.

16. Kraehmer , H., Bernd Laber , chris Rosinger and A. Schulz .2014. Herbicides as weed control agents : state of the art : 1- weed control research and safener technology : The path to Modern Agric . plant Physiology 166 : 1119-1131 . DOI: https://doi.org/10.1104/pp.114.241901

17. Lahmoud, N. R. 2012. Allelopathic Effects of Sorghum bicolor .Moench in Flanking Jungles and Subsequent Yield. Ph.D. Dissertation. Department of Field Crop Sciences - College of Agriculture - University of Baghdad. Republic of Iraq pp: 135.

18. Liebl , R. and A.D.Worsham . 1987. Interferon of Italian ryegrass (Lolium multiflorum ) in wheat (Triticum aestivum L.) .Weed Science. 35:819-823

19. Mohammed F.H.K.AL-Hassanm, A.Jaddoa and A.H. Saudi .2014. Respons to several varieties of wheat news (Triticum aestivum L.) rates for different seed. 3, Issue 1, pp: $143-165$

20. Moody, K. and M. T. Madrid. 1983 . Rice Cultivar Tolerance to Herbicide . Technical Bulletin 76 . IRRI, Los Banos . Ohilippines, pp:14

21. Narsaiah , B.D. and R.G.Harver .1977. Differential response of corn in breds and hybrids to alachlor. Crop.Science. 17:657

22. Nihaya, .R.S. 2004. The Effect of Plant Distribution on the Growth and Grain Yield of Three Varieties of White Corn. M.Sc. Thesis Department of Field Crops Sciences - College of Agriculture - University of Baghdad. pp. 52 23. Rajaram.S. 2002. Prospect and Promise of Wheat Breeding the $21^{\text {th }}$ century $6^{\text {th }}$. Wheat Conf Budapest . Hungary. pp: 24 
24. Shati , R . K.2014. Influence of certain herbicides on Soft Wheat (Triticum aestivum L. ) in Iraq . Jordan Journal of Agriculture. Sciences. 10(2) : 253-272

25. Shekhhazad , V.,Fili , M.R.V.,B. Mirshekari and F. Farahvash .2012. Weed control in wheat fields by limited dose of postemergence herbicides . World Applied Science. J.16(9):1243-1246

26. Tollanaar, M.,A. Aguilera and S.P.Nissanka . 1997. Grain yield is reduced more by weed interference in an old than in a new maiz hybrid . Agronomy Journal.89:239246

27. Tollanaar, M.S.P.Nissanka , A.Aguilera . f.F. weise and C.J.swanson . 1994. Effect of weed interference and soil nitrogen on four maiz hybrids. Agronomy Journal.86:596-601 28. Wright, T.H. and C.E.Rieck . 1973. Differently butylate injury to corn hybrids. Weed science. 21:194-19 